\title{
THE SIGNIFICANCE OF THE CONCEPT OF THAUMA IN PATOČKA'S PHILOSOPHY OF THE HISTORY OF ART
}

\author{
FELIX BORECKÝ
}

\begin{abstract}
In his essays on general history, Patočka locates the thaumatical shake-up together with the beginning of philosophy, politics, and history in classical Greece, when man first stepped back from being and became able to reflect freely upon everything that exists (his Lebenswelt). The author seeks to demonstrate that a similar thaumatical shake-up also occurred in art history with the coming of the aesthetic era. Here, art no longer serves to affirm a religious or ideological order, as it had in the preceding artistic era; instead, art turns towards the individual, who, by means of the work of art, reflects upon the world he or she lives in.

The author concludes that the art of the artistic era has similarities with the pre-historical age in which thauma was not yet present, and the art of the aesthetic era shares features with the historical age in which, by contrast, thauma is the central factor. Liberating wonder brought the pre-historical age to an end in ancient Greece with the discovery of philosophy, politics, and history, giving birth to the historical age in Europe. By contrast, the artistic era did not cease to be dominant till modern times; it was then that thauma became the crucial aspect for the reception of art and gave birth to the aesthetic era. Here, the philosophy of art or aesthetics, the history of art, and the politics of art were revealed. Key words: Jan Patočka; thauma; history of art; artistic era; aesthetic era
\end{abstract}

\section{LE SENS DU CONCEPT THAUMA DANS LA PHILOSOPHIE DE L'HISTOIRE DE L'ART DE PATOČKA}

Dans les textes consacrés à l'histoire générale, Patočka relie l'ébranlement thaumatique à la naissance de la philosophie, de la politique et de l'histoire dans la Grèce antique, au moment où, pour la première fois, l'homme, s'émancipant de l'étant, est parvenu à réfléchir librement l'ensemble de l'existant (le vécu). Dans notre essai, nous cherchons à montrer qu'un pareil ébranlement thaumatique a eu lieu dans l'histoire de l'art, avec l'avènement de l'ère esthétique. C'est à partir de ce moment que l'art n'a plus servi à affirmer un ordre religieux ou idéologique, comme c'était le cas lors de précédente ère artistique, mais qu'il s'est tourné vers l'homme en tant qu'individu qui, par l'intermédiaire de l'œuvre d'art, réfléchit sur son existence.

De là, il est possible de conclure que l'art de l'ère artistique ressemble à l'époque pré-historique où le thauma n'était pas encore présent, et que l'art de l'ère esthétique partage des traits communs avec lépoque historique dans laquelle le thauma constitue, au contraire, le facteur central. Un étonnement libérateur est venu conclure l'époque pré-historique dans la Grèce ancienne, avec l'avènement de la philosophie, de la politique et de l'histoire, donnant ainsi naissance à l'époque historique de l'Europe. La domination de l'ère artistique, ne cesse pour sa part qu'à l'époque moderne où le thauma devient l'aspect crucial pour la perception de l'art, entraînant le passage à l'ère esthétique. C'est à partir de ce moment que se développent la philosophie de l'art, l'esthétique, l'histoire de l'art et la politique de l'art. 


\section{VÝZNAM POJMU THAUMA PRO PATOČKOVU FILOSOFII DĚJIN UMĚNÍ}

Ve studiích věnovaných obecným dějinám Patočka thaumatický otřes spojuje se vznikem filosofie, politiky a dějin v období klasického Řecka, kdy člověk poprvé odstupuje od jsoucna a dokáže poprvé svobodně reflektovat vše stávající (svůj životní svět). Snažíme se ukázat, že k podobnému thaumatickému otřesu dochází i v dějinách umění, a to s př́íchodem tzv. estetické éry. V ní umění přestává sloužit k potvrzování náboženského či ideologického řádu, jako tomu bylo $v$ předchozí éře umělecké, a obrací se $\mathrm{k}$ člověku jako $\mathrm{k}$ individuu, jež prostřednictvím uměleckého díla reflektuje svět svého života.

Docházíme $\mathrm{k}$ závěru, že umění tzv. umělecké éry vykazuje podobné vlastnosti $s$ před-dějinnou epochou, $\mathrm{v}$ níž ještě není thauma přítomné, a umění tzv. estetické éry má zase styčné rysy s epochou dějinnou, $v$ níž je naopak thauma zásadním činitelem. Předdějinnou epochu ukončuje osvobodivý údiv již v období klasického Řecka objevením filosofie, politiky a dějin a dává zrod evropské dějinné epoše. Umělecká éra naproti tomu přestává být dominantní až $\mathrm{v}$ moderní době, kdy se thauma stává pro recepci umění klíčovým aspektem a dává vznik éře estetické. $V$ ní se objevuje filosofie umění neboli estetika, dějiny umění a politika umění.

Jan Patočka belongs to those philosophers that situate the beginning of European thinking and the origin of history in classical Greece from the fifth to the fourth century BC. In Patočka's reflections on history, classical Greece represents the point when the two basic ages, the pre-historical and the historical, split. Only at that time was man able to step back from the collectively binding meaning of myth; only the Greek could, for the first time, consciously reflect on the whole world he lived in and could unfold 'the possibility basic to human beings, to win or lose themselves. ${ }^{1}$ In accordance with a great number of other thinkers, Patočka traditionally refers to Aristotle's concept of thauma, which Aristotle, in his first book of Metaphysics, described as the inception of all knowledge (thauma arche tès sofías - wonder is the beginning of wisdom). ${ }^{2}$ This wonder, this awe at what actually is, ${ }^{3}$ is a productive condition to take up a free relation to the world, and it is only by virtue of this wonder that philosophy, politics, and history were born in classical Greece. In formulations of what this first thaumatical distance is, Patočka often uses the Czech word otřes (a shaking-up). Recall the passage from Heretical Essays in which Patočka describes this thaumatical shaking-up:

Nothing of the earlier life of acceptance remains in peace; all the pillars of the community, traditions, and myths, are equally shaken, as are all the answers that once preceded questions, the modest yet secure and soothing meaning, though not lost, is transformed. It becomes as enigmatic as all else. Humans cease to identify with it, myth ceases to be the word of their lips. In the moment when life renews itself everything is cast in a new light. Scales fall from eyes of those set free, not that they might see something new but that they might see in a new way. ${ }^{4}$

1 Jan Patočka, Heretical Essays in the Philosophy of History trans. by Erazim Kohák (Illinois: Open Court, 1996), 36.

2 Ibid., 40. See also Aristotle, Metaphysics, trans. William David Ross (Blacksburg: Virginia Tech, 2001), 4: 'For all men begin, as we said, by wondering that things are as they are.'

3 Patočka, Heretical Essays, 40.

4 Ibid., 39-40. 
The human beings of the pre-historical age lived in immediacy, their lives were not yet problematic, the openness of being was not yet revealed, 'humanity here [in that age] lives only in order to live, not to seek deeper, more authentic forms of life. ${ }^{5}$ They concentrated on the acceptance and preservation of life (protection, work, production). The global meaning of life was prescribed to them by mythical-religious notions which were collectively binding within society. According to Patočka, no great difference exists between natural societies (non-historical events of primeval societies) and pre-Greek civilizations (prehistorical events); consequently, the difference between the two consists only in the degree of the maintenance of its traditions. (Above all, the invention of writing helps to maintain complicated rituals and to develop more complex social organization.) For both of them, it holds that the meaning of a man's life is determined by the collectively binding traditions and myths. Pre-historical people accepted the global meaning without questioning it, and were in agreement with it in the society.

Only thanks to the thaumatical shaking-up did man actively step back from accepted meaning and become free. By virtue of this distance, man consciously and on his own achieved the meaning of his existence, for which he assumes responsibility. The global meaning of his existence and of the world he lives in is no longer provided by any mythological-religious system or ideology; from now on, it is up to the individual to take care of it (care of the soul; péče o duši). The thaumatical shock is thus a trigger quality that can lead man to authentic global meaning and the natural world: thanks to global meaning, man finds orientation in the fundamental relations of his being in the world, his natural world. Thauma raises doubts about an assured accepted life, the distance of it, and the unfolding of the free bestowing of meaning to new possibilities of our lives. Thauma is formative not only for the birth of philosophy, but also for the discovery of politics and history.

In the further historical development, this free access to philosophy, politics, and history was dwindling away. Whereas the ancient Greek emerged from the wonder by means of which he found the global meaning of his life and orientation in the world he lived in (Lebenswelt), the following periods did not return to the thaumatical shaking-up, and instead substituted metaphysics for it. Metaphysics turns away from thauma; it takes a particular meaning and makes it absolute: it transforms this meaning into a necessary, universal truth which is eternally valid under any circumstances. Instead of coming out of the field of appearance, the truth of metaphysics is based on an indubitable construction. The most influential conceptions of metaphysics, in Patočka's view, are Platonism (ideas as eternal and immutable beings), Democritean atomism, Christianity, which is, together with the idea of the eternal and infallible God, based on Platonism, and modern mechanical metaphysics.

The last-mentioned type of metaphysics, according to Patočka (following Husserl's Crisis), is the most dangerous. Modern science introduced the 'invention of idealization', promoting the idea that the right world is in itself the world of science, and that what we experience in the current natural world is but a contingent subjective untruth. ${ }^{6}$ Ancient

5 Ibid., 29.

${ }^{6}$ Edmund Husserl, The Crisis of European Sciences and Transcendental Phenomenology, transl. by David 
science did not yet know this kind of consistent idealization, and idealized only certain 'islets of reality', in particular geometric figures. Contrary to this, modern science 'thus seeks to control nature in its totality. ${ }^{\text {? }}$

Modern man therefore lives in a bivalent world: 'the world that naturally surrounds him and the world produced by modern science based on the mathematical laws of nature. This disunity, which pervades all our lives, is the true cause of the spiritual crisis we are going through.' ${ }^{8}$ This schizophrenia, typical of modern man, is difficult to overcome. The modern era no longer provides global meaning common to all society; the old ideological orders became untrustworthy. The dominating science (natural meta-physics) is unable to accomplish this aim, because science, by definition, is limited to a certain area of reality owing to strictly determined axioms. It is able to provide only particular meaning. Similarly, philosophy, despite its role of providing an 'unfragmented spiritual view of the whole', cannot, in the reality of the modern era, achieve this aim. ${ }^{9}$

\section{III}

The only spiritual activity that for modern man can moderate this ambiguity between the world of science and technology on the one hand and the world he experiences on the other is art. The principal function of art, according to Patočka, is to reveal to man the global meaning of his life and to remind him of the natural world. Patočka defines the 'natural world' as that which is given 'without explicit theoretical endeavour, without theoretical effort and art, that is, naturally [...], the most characteristic trait of the natural world we consider that there is without our free intervention, based solely on the mere fact of our experience before all our theoretical standpoints. ${ }^{10}$ The basic aim of phenomenology is to reveal and describe this primordial world and the things in it, as they naturally appear to man and as man encounters them in the pre-theoretical world. If art is able to achieve this aim, then it is not surprising that Patočka considers art to be the chief domain that phenomenology should investigate.

Art and art history constitute the main theme of Patočka's essay 'Art and Time. ${ }^{11}$ Here, he distinguishes the history of art between the artistic and the aesthetic era. (This division is implicitly present in most of Patočka's writings on art.) Let us briefly recall the basic

Carr (Evanston: Northwestern University Press, 1970), 48-49: 'But now we must note something of the highest importance that occurred even as early as Galileo: the surreptitious substitution of the mathematically substructed world of idealities for the only real world, the one that is actually given through perception, that is ever experienced and experienceable - our everyday life-world.'

7 See Jan Patočka, 'Spisovatel a jeho věc', in Jan Patočka, Češi I (Prague: OIKOYMENH, 2006), 285: 'usiluje takto zvládnout prírodu v jejím celku'.

8 Jan Patočka, 'Přirozený svět jako filosofický problém', in Jan Patočka, Fenomenologické spisy I, (Prague: OIKOYMENH, 2008), 129: 'totiž ve svém přirozeně daném okolí a ve světě, který pro něj vytváří moderní prŕrodověda, založená na zásadě matematické zákonitosti přírodní. Nejednota, která tím prostoupila celý náš život, je vlastním zdrojem duševní krize, kterou procházíme.'

9 Patočka, 'Spisovatel a jeho věc', 292: 'neroztř́šstěný duchovní pohled na celek'.

10 Patočka, 'Přrirozený svět jako filosofický problém', 134. 'bez našeho výslovného teoretického přičinění, bez teoretického úsilí a umění, tedy přirozeně [...], za jeho rys nejcharakterističtější pokládáme, že jest $z$ de právě bez našeho svobodného zásahu, na základě pouhého faktu naší zkušenosti přede vším stanoviskem teoretickým.'

11 Jan Patočka, 'Umění a čas', in Jan Patočka, Umění a čas I (Prague: OIKOYMENH, 2004), 303-18. 
characteristics of the two eras. The art of the artistic era serves the religious or ideological order in a particular society and confirms the course of that society. In mythical times, in classical antiquity, the Middle Ages, and the beginning of the modern era, the aesthetic experience elevated man to the global meaning that was common to all members within that society; since collectively binding, it was commonly accepted. Thus, for example, Phidias' Statue of Zeus at Olympia is proof of the ubiquitous rule of the gods over terrestrials in ancient times, or, similarly, a Gothic church affirms that the Christian order administers the operation of the world.

In the modern, aesthetic era, art also elevates man from everyday concerns towards the global meaning of life. This meaning is no longer collective; it is individual. From this point on, art turns towards individuals, and initiates the articulation of the proper existential meaning of an individual man. Cézanne's or van Gogh's paintings do not affirm the ruling order in the world, but instead stimulate the spectator to articulate his or her proper understanding of the world. Patockka says that these works of art express the world in themselves.

The aim of art in both eras is thus to recall the natural world and to provide global meaning. Yet they are radically different. The aesthetic perception of the ancient Greek was completely different from that of modern man. For a Greek of the fifth century BC, Phidias' Statue of Zeus was a symbol that referred to something he considered to really exist, something on which he agreed with other members of the community (polis), that is to say, it referred to the Deity that directs the cosmos. This collectively binding meaning is no longer present in the art of the aesthetic era. Giacometti's figurative sculpture is a symbol whose meaning culminates in the singular interpretation of a specific spectator. It is rather a dialogue between the work of art and its spectator, and its result is the constitution of an individual existential meaning.

\section{IV}

In Heretical Essays, the theme of art is not the focus of Patočka's attention. Here, he relates revelation of thauma to the philosophy, history, and politics of classical Greece, but he does not mention what happened to art and its development. I assume that the artistic era, discussed in 'Art and Time', shares traits with Patočka's description of the prehistorical age in Heretical Essays. Much as in the prehistorical age, in the artistic era man's understanding of the natural world and global meaning is non-problematic. By means of art, man turns towards global meaning, but he does not assume it to be a problem. The turning point was at the beginning of the modern era, and it is closely related to the development of modern science. From that time on, the unprecedented discrepancy between science (and technology, its product) and the world we live in (the natural world) increases, and we, modern people, cannot easily reconcile the two. It is precisely in this era that the role of art is more important than ever before. Art in the modern era remains the spiritual activity that can recall the entirety of life, but in the new aesthetic era it stops being at the service of the collective ideological order, because this collectively shared order providing commonly binding global meaning no longer exists. Unlike Phidias' statue, which recalled the rule of the gods on Earth, and unlike the Gothic and even the 
Baroque church, which represented the proof of the existence of the Holy Trinity, the art of the aesthetic era turns towards man as an individual. Global meaning is constituted from the dialogue between the work of art and the spectator.

Is this transformation of the function of art in the modern age not similar to the falling of the scales from the eyes with which Patockka describes the origin of philosophy, politics, and history in classical Greece in the fifth and forth centuries BC? Is the advent of the aesthetic era not analogous to these miraculous forms of reflection that ancient Greece arrived at in philosophy, politics, and history? And is Greek thauma not necessary for the revelation of aesthetics?

The fundamental feature (we may say necessary condition) of the modern approach to art is precisely this wonder, this innovative quality of the work of art. This quality leads the spectator towards the work of art and stimulates him or her to take an aesthetic attitude. The art of the artistic era naturally also abounds with aesthetic qualities that have led man from practical concerns towards aesthetic contemplation, but only since the modern aesthetic era has man been stimulated to perform this contemplation on his own, individually. The modern spectator stands in front of the work of art not as a member of a collective but as an individual.

If the art - of both the artistic and the aesthetic era - is a 'reminder of the global meaning of life' (pripomínka celostního životní smyslu), that is, if art leads man to reflect on the essential relations of the natural world, then the art of the aesthetic era must be thaumatical. Modern aesthetics often uses the term 'deformation' or 'defamiliarization'. The innovative (deformative) power of art has now become important. The reason why modern art increasingly concentrates on originality and stylistic refinement is that the function of the art of the aesthetic era is to shake up the given meaning and awaken reflection on man as andividual and on the world he lives in.

This concerns several important aspects which are not explicitly developed by Patočka. The aesthetic attitude was born in the aesthetic era. If art no longer affirms the accepted world (if art is no longer part of the world man lives in), but instead creates an alternative world whose depiction leads man to reflect on the accepted world, then a need arises to introduce a special concept that describes and delimits a reflective attitude of this kind. The aesthetic attitude constitutes a cornerstone of modern aesthetics, and occurs in the writings of most of the leading scholars in the field.

The history of art began to develop in the aesthetic era. The significance of artistic value increases, and a related question is to be posed: when was the work of art created and when did it become to any extent innovative regarding the historical phase it belongs to? 'Progress' in art, the idea that each new work of art has to be an informed surpassing of preceding works of art, is a fundamental axiom of the reception of modern art.

Furthermore, the politics of art was born. The artist lost his position in the community and created, with his work, an alternative community. He has ceased to be an ordinary artisan working to fulfil the orders of a governing ideology, and is instead someone who strives to express alternatives. While ancient art obediently served its community and was politically engaged without reflecting on this engagement, the degree of engagement became an important theme in the aesthetic era. In other words, the political impact of art began to be reflected on. 
As the revelation of thauma in ancient Greece was connected with the birth of philosophy, history, and politics, so too were the philosophy of art or aesthetics, the history of art, and the politics of art discovered with the advent of the aesthetic era.

\section{V}

Although Patočka's thaumatical understanding of the art of the aesthetic era implicitly considers these traits of modern art, one must not forget that the main function that Patocka attributes to the art of both eras is a cognitive one. Art has to express the essential relations of man's being in the world. In the modern, aesthetic era, the role of thauma acquires great importance because it is more and more difficult to arrive at the natural world and the global meaning of life. For Patocka, thauma is above all the means by which we can attain cognition, the truth. If man in the modern era had not lost his consciousness of global meaning, art would not have been expected to be full of this innovative quality which initiates reflection.

We find two traits implicit in Patočka's reflections on the art of the aesthetic era. The first trait, common to both the artistic and the aesthetic era, consists in expressing man's essential relations with the world. The second trait, proper only to the art of the aesthetic era, is the innovative power of thauma. Both traits are extremely important, and if one or the other is missing in a modern aesthetic object, then it cannot be considered art in the true sense of the word. Rather, it will be an unsuccessful candidate for a work of art or quasi-art.

(1) Works of modern art which are based only on defamiliarization are, in Patočka's view, barely worth acknowledging. As a philosopher who looks for ways to take up the authentic global meaning of life in dispersive modern civilization, Patočka would consider useless most art works that do not seek to do anything but shock or amuse. To provoke a deformation which lacks a profounder aim, which does not have anything to reflect upon, which has nothing to say, would, for Patočka, not be a real art. Regarding Patočka's prevailing conservative interpretations of specific art works and artists, ${ }^{12}$ we may reasonably suppose that he would categorize most works of modernism and the Avant-garde as quasi-art. As a defender of the cognitive dimension of art, Patočka would consider these works as newer forms of art for art's sake, that is, something far from his own standpoints.

(2) But an absence of innovative power in a modern work of art is, for Patočka, an equally fatal shortcoming. If the art of the modern era seeks to express an essential aspect of the lived world without choosing to depict this with deformative qualities, but, by contrast, relies on forms that have already been used, then it will only be quasi-art, as in the formalism of art for art's sake. Patočka would likely declare such art to be derivative or art that seeks only commercial success (consumer art). The essential is expressed only by means of pertinently chosen qualities, which have finger on the pulse of their times, but also arouse the wonder that is indispensable for the reception of modern art.

12 In his considerations, we encounter authors such as Karel Hynek Mácha, Karel Jaromír Erben, L. N. Tolstoy, F. M. Dostoyevsky, William Faulkner, Thomas Mann, A. P. Chekchov, Jaroslav Durych, and Ivan Vyskočil, but almost no one writing in the styles of the Avant-garde (art for art's sake, Surrealism, and so on). 
Hence, Patočka requires that real art have both of these traits. In the essay 'Art and Time', he emphasizes the innovative feature thauma; in the essay 'The Writer and His Cause' and in most of his essays on specific works of art, he accentuates the expression of the essential.

\section{VI}

The philosophical aspect, thauma, must be present in the aesthetic experience of man in the modern, aesthetic era. Art as art was not revealed in ancient Greece but in the modern era. Patočka attributes a positive function to the modern era (which is rejected by phenomenologists because, among other things, it entails the loss of the natural world, the introduction of technology into all aspects of human life, and brought about the oblivion of being). A very important insight of Patockka's is that he contemplates the history of art in relation to the history of science and technology. The relationship between them can usefully be characterized as a relation of direct proportionality. The greater the difference between the scientific worldview and the natural world, the greater the need for aesthetically experienced art. In 'Art and Time', Patočka writes that the transformation of the artistic era into the aesthetic era occurred in the late nineteenth and the early twentieth century. ${ }^{13}$ In my opinion, this date should be considered not the beginning of the aesthetic era but the peak of a long-lasting dynamic process. We can easily find works of art which anticipate aesthetic perception before the late nineteenth and early twentieth centuries (for example, in literature, in the works of Cervantes, Sterne, and Diderot.) In Patočka's thinking, the influence of non-artistic reality on the development of art is not negligible, even though in modern times it is increasingly overwhelmed by science and technology.

One may reasonably object that Patočka's conception of politics and history, as defined in his Heretical Essays, is too closely bound to what they have in common with philosophy. It is more difficult to find particular differences in Patočka's formulations. The common feature, crucial to the birth of all three domains, a feature that could even be called a model, is thauma.

In the political domain, the ancient Greek liberated himself from life in the 'great household', transforming his hitherto accepted life in such a way that he recognized other people as free and equal to himself. He sought to develop communal life and, within this collective of mutually equal people, to develop his own human possibilities. ${ }^{14}$ The process was similar in the historical domain. The ancient Greek ceased to maintain the immutable tradition that had been fully accepted by pre-historical civilizations. By actively distancing himself from pre-historical times, he entered history, and his life was freed from traditions. Eventually, philosophy was born of the same thaumatical trunk.

Doubting all the certainties of accepted life and, in addition, distancing oneself from these certainties leads one to the development of free thinking and to freely bestowing

13 He calls it a 'real revolution'. Patočka, 'Umění a čas', 303.

14 Political life consists in 'demonstrating that in which humans can be in principle equal in competition with each other'. Patočka, Heretical Essays, 38; In Czech: 'V politickém životě jde o "předvedení toho, čím člověk může být v závodu se sobě zásadně rovnými”". Patočka, Kacírské eseje, 49. 
meaning to new possibilities of life. Thanks to thauma, the ancient Greek no longer naively accepted his life as something self-evident, but fundamentally transformed it into an initiative revealing philosophy, politics, and history.

It is fair to object that Patočka is reductive in his consideration of politics and history when he concentrates only on the common denominator of thauma. His conception of politics has been criticized by Petr Rezek as overly philosophical. Unlike in philosophy, in the domain of politics one need not remain on the boundary of the world, experiencing the difference between appearance $(z j e v)$ and what makes appearance possible (zjevování), that is, experiencing 'the explicit relation with Being. ${ }^{15}$ Following Hannah Arendt, Rezek assumes that engagement in the world is central to political action in which, unlike philosophy, man does not experience a relationship with that which makes appearance possible at all. For this reason, rather than 'that which makes appearance possible', it would be more precise to use the term 'appearance', which is more suitable to the domain of the politician. Patočka's philosophical conception of politics cannot grasp action in the world, including political action. It grasps only action that remains on the boundary of the world. ${ }^{16}$

Similarly, one may criticize Patočka’s conception of history. For example, Hans-Georg Gadamer, who shares Patočka's philosophical point of departure for understanding the foundation of history, offers convincing arguments that history has been revealed by modern man and not, as Patočka asserts, by the ancient Greek. Gadamer declares that the revelation of historical consciousness is:

very likely the most important revolution among those we have undergone since the beginning of the modern epoch. Its spiritual magnitude probably surpasses what we recognize in the applications of natural science, applications which have so visibly transformed the surface of our planet. [...] Our present-day consciousness of history is fundamentally different from the manner in which the past appeared to any foregoing people or epoch. We understand historical consciousness to be the privilege of modern man to have a full awareness of the historicity of everything present and the relativity of all opinions. [...] Today no one can shield himself from this reflexivity characteristic of the modern spirit. ${ }^{17}$

Is this Gadamerian determination not more acceptable? According to Patočka, the ancient Greek discovered history while casting doubt on the mythological traditions of preceding cultures and while defining himself against them. Does not the right revelation of history consist rather in what Gadamer describes, in awareness of the historical relativity that concerns not only the past of preceding cultures and traditions but also the present in which the man who looks at the past and researches it lives. ${ }^{18}$

15 Petr Rezek, 'Životní pohyb pravdy a život v pravdě u Jana Patočky', in Petr Rezek, Filosofie a politika kýče, (Prague: Jan Placák - Ztichlá klika, 2007), 93.

16 Rezek, Filosofie a politika kýče, 104.

17 Hans-Georg Gadamer, 'The Problem of Historical Consciousness', trans. by Jeff L. Close, Graduate Faculty Philosophy Journal, 5:1 (1975): 8.

18 It would be worth comparing Gadamer's profound considerations on the history of art with Patočka's. Whereas Patockka sees the crucial rupture between the old and modern art, Gadamer poses the task of 'bridging the enormous gap between the traditional form and content of Western art and the ideals of contemporary artists.' Hans-Georg Gadamer, The Relevance of the Beautiful, Trans. Nicolas Walker (New York: Cambridge University Press, 1998), 12. By means of the concepts of play, symbol, and 
In this essay, instead of a critique of Patočka's concepts, I have followed his considerations of the thaumatical foundation of spiritual actions, such as philosophy, politics and history, and I have attempted to reconsider them for the sphere of art. Analysing Patočka's thinking, I have come to the conclusion that the art of the artistic era has similarities with the pre-historical age in which thauma was not yet present, and, the art of the aesthetic era shares features with the historical age in which, by contrast, thauma is the central factor. Liberating wonder brought the pre-historical age to an end in ancient Greece with the discovery of philosophy, politics, and history, giving birth to the historical age in Europe. By contrast, the artistic era ceased to be dominant, not before modern times, when thauma became the crucial aspect for the reception of art and gave birth to the aesthetic era. Here, the philosophy of art or aesthetics, the history of art, and the politics of art are revealed.

\section{BIBLIOGRAPHY}

Aristotle, Metaphysics. Translated by William David Ross. Blacksburg: Virginia Tech, 2001.

Gadamer, Hans-Georg. 'The Problem of Historical Consciousness'. Translated by Jeff L. Close. Graduate Faculty Philosophy Journal, 5:1 (1975): 8-52.

- The Relevance of the Beautiful. Translated by Nicolas Walker. New York: Cambridge University Press, 1998.

Husserl, Edmund. The Crisis of European Sciences and Transcendental Phenomenology. Translated by

David Carr. Evanston: Northwestern University Press, 1970.

Patočka, Jan. Češi I, Prague: OIKOYMENH, 2006.

—. Fenomenologické spisy I. Prague: OIKOYMENH, 2008.

- Heretical Essays in the Philosophy of History. Translated by Erazim Kohák. Illinois: Open Court, 1996.

Péče o duši III. Prague: OIKOYMENH, 2002.

- Umèní a čas I. Prague: OIKOYMENH, 2004.

. Uměni a čas II. Prague: OIKOYMENH, 2004.

Rezek, Petr. Filosofie a politika kýče. Prague: Jan Placák - Ztichlá klika, 2007.

feast, Gadamer reveals 'anthropological foundations upon which the phenomenon of art rests and from the perspective of which we must work out a new legitimation for art.' Gadamer, Relevance of the Beautiful, 5. 